\title{
Nepal Sanitation Movement Lessons Learnt on Targets and Monitoring
}

DATE PUBLISHED June 2021

AUTHOR Kamal Adhikari and Bharat Adhikari

Sanitation Learning Hub Case Study
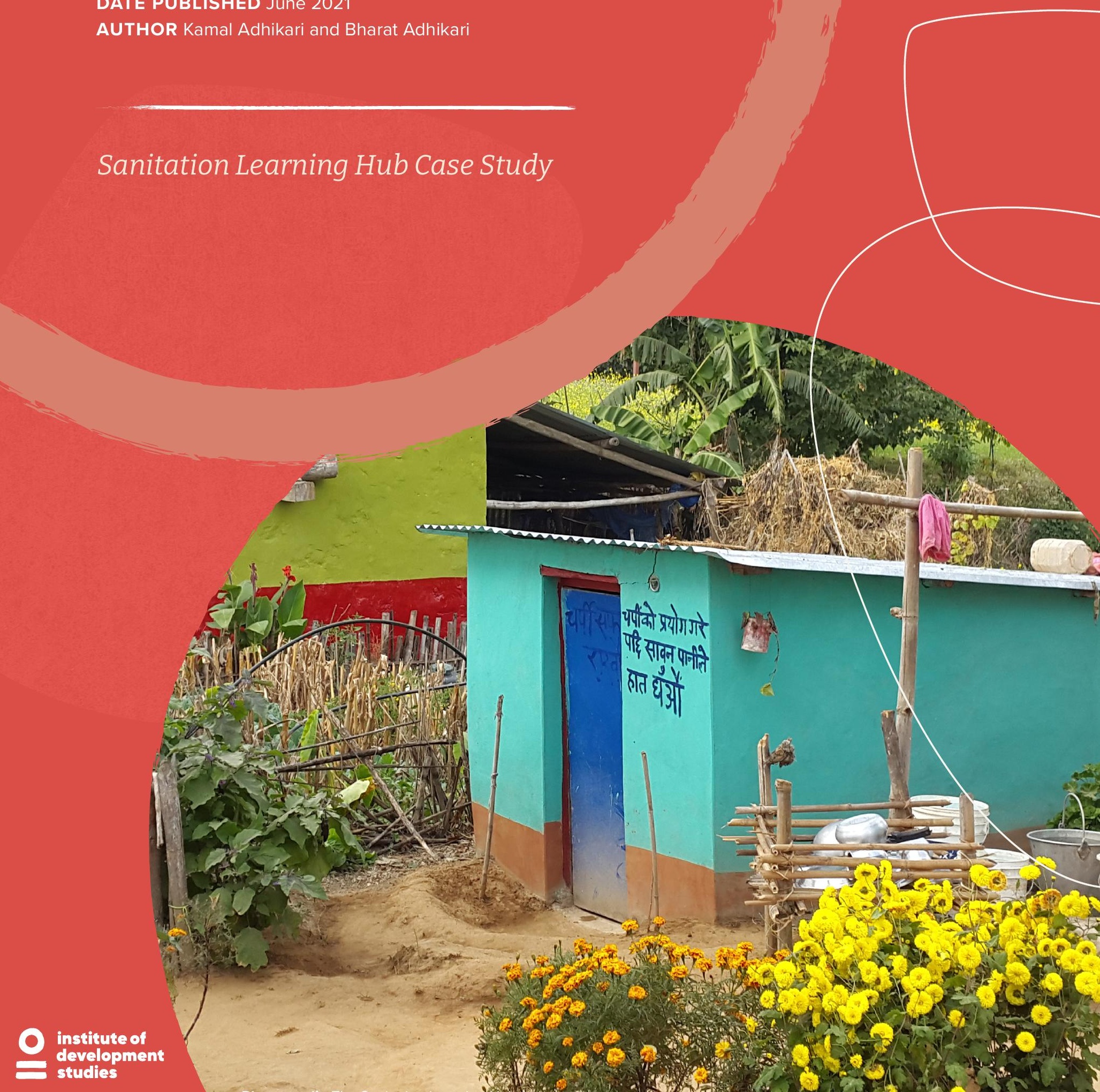


\section{Table of Contents}

Table of Contents

List of Acronyms and Abbreviations

List of Tables, Boxes and Figures

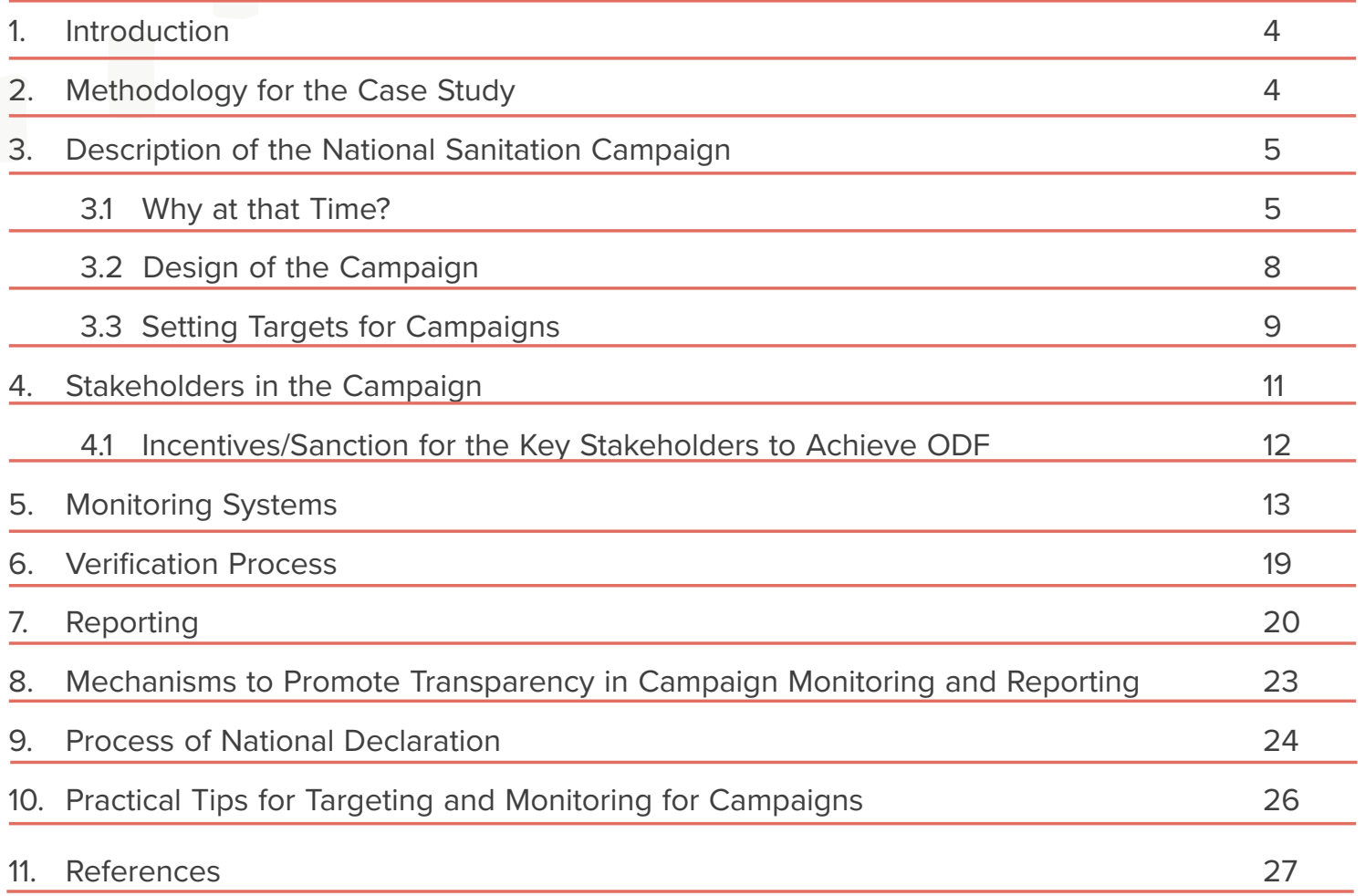




\section{List of Acronyms and Abbreviations}

CSOs: $\quad$ Civil society organisations

DWSS: $\quad$ Department of Water Supply and Sewerage

DWSSM: Department of Water Supply and Sewerage Management

JSR: Joint sector review

IDWSSD: International Drinking Water Supply and Sanitation Decade

MAT: $\quad$ Monitoring and Action Team

NMIP: $\quad$ National Information Management Project

NPC: $\quad$ National Planning Commission

NGOs: Non-governmental organisations

NSHCC: National Sanitation and Hygiene Coordination Committee

NSHSC: National Sanitation and Hygiene Steering Committee

ODF: $\quad$ Open defecation free

SAP: $\quad$ Social Accountability Programme

SDG: $\quad$ Sustainable Development Goal

VDC: Village development committee

WASH: Water, sanitation and hygiene

WASH-CC: $\quad$ WASH Coordination Committee

WSSCC: Water Supply and Sanitation Collaborative Council 


\section{List of Tables, Boxes and Figures}

Tables

Table-1: Types of Data, Methods, and Tools

Table-2: Monitoring System

Table-3: Reporting Mechanism

Boxes

Box-1: Factors Strengthening Sanitation Campaign

Box-2: Steps of Verification

Box-3: Incentives and Sanction to Stakeholders for Honest Reporting

Figures

Fig.1: Map of Nepal

Fig.2: Monitoring Guidelines of Morang District

Fig.3: Social Map of Catchment Area of Nepal National Lower Secondary School in Bara District

This case study accompanies the publication:

'Monitoring sanitation campaigns: Targets, reporting and realism'

Frontiers of Sanitation: Innovations and Insights 18

by Kamal Adhikari, Bharat Adhikari, Sue Cavill, Santosh Mehrotra, Vijeta Rao Bejjanki and Matteus Van Der Velden 


\section{Introduction}

Both national and global commitments have made governments around the world responsible for achieving open defecation free (ODF) status for public health improvements. Many Asian and African countries including Nepal have organised ODF campaigns to achieve the country target on sanitation alongside their national policies, plans and strategies.

After enforcement of the Sanitation and Hygiene Master Plan 2011 (herein after referred to as the Master Plan) government agencies and stakeholders were able to nurture and scale up the sanitation campaign by unifying ongoing community-level sanitation activities under the planning, target setting, financing, and monitoring processes at district and local levels (municipality, rural municipality, village development committee, and ward). Coverage increased by 57 per cent after the Master Plan's enforcement. Since the inception of the Master Plan, sanitation coverage has accelerated by an average of 7 per cent per year (compared with an average of 4 per cent per year over the previous decade), with the government of Nepal declaring the country ODF on 30 September 2019 (WSSCC 2019).

The Master Plan involved proactive leadership of multi-sector collaborative efforts, at national and sub-national levels. Activities and approaches included:

- Decentralised and participatory planning.

- Site-specific target-setting approach.

- Intensive advocacy campaign.

- Media engagement.

- Non-governmental organisation (NGO) engagement.

- Civil society Organisation (CSO) engagement.

- Wider sector triggering approach.

- Widespread community capacity development and empowerment.

- No subsidy approach.

- Targeted local-level support to poor and disadvantaged communities.

- Joint monitoring, evaluation, and verification.

The district and local level had full autonomy to set milestone and sanitation targets within the overall national deadline, based on their place-specific sanitation status and stakeholders' capacity.

The Sanitation Learning Hub commissioned case studies of sanitation campaigns in both Nepal and India, drawing out the lessons learnt for other countries wishing to implement similar initiatives. Both case studies focus on how target setting and feedback and reporting mechanisms can be used to increase the quality of campaigns. ${ }^{1}$

\section{Methodology for the case study}

A two-member research team of water, sanitation and hygiene (WASH) professionals prepared this case study for Nepal, using primary and secondary information. Considering the COVID-19 situation, primary information was collected through in-depth interviews and a focus group discussion using telephone/Viber calls and Zoom/Skype meeting respectively. In-depth interviews provided respondents time to express subtle perspectives, whereas focus groups enabled crossquestions, counter arguments, and further clarifications. The secondary information helped to triangulate primary data. The types of data, methods, and tools of data collection as well as number of respondents are presented in Table 1. 


\begin{tabular}{|c|c|c|}
\hline DATA TYPES & DATA COLLECTION METHOD & NUMBER OF RESPONDENTS \\
\hline \multirow[t]{2}{*}{ A. Primary } & In-depth interviews & 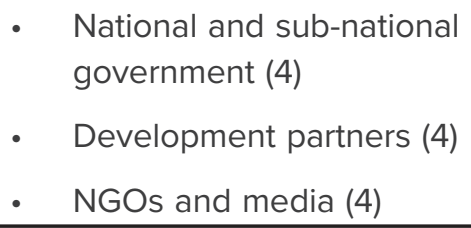 \\
\hline & Focus group dicussion & $\begin{array}{ll}\text { - } & \text { Officials of local } \\
\text { government (1), } \\
\text { - } & \text { Schools (1) } \\
\text { - } & \text { NGOs (3) } \\
\text { - } & \text { Media (2) }\end{array}$ \\
\hline B. Secondary & Desk Review & $\begin{array}{l}\text { Review of sanitation sector } \\
\text { policies, plans, papers, sector } \\
\text { publications, progress reports, } \\
\text { and study documents. }\end{array}$ \\
\hline
\end{tabular}

Prior to the in-depth interviews and focus groups, study questionnaires were tailored and translated into the Nepali language. Research objectives and questions and shared with respondents in advance, along with an email describing the purpose, ethics, and protocol of the study. The respondents (policymakers, planners, and field-level practitioners) were purposively selected for their contribution to the sanitation campaign. A little difficulty was faced in soliciting timely information from respondents residing at sub-national levels.

\section{Description and history of the national sanitation cam- paign}

\subsection{Why at that time?}

The sanitation campaign in Nepal emerged and propagated spontaneously from grass-root communities. It gained momentum after 2011 through the collaboration of cross-sector stakeholders, who strategically engaged various national- and sub-national-level coordination mechanisms led by the government.

\section{Key challenges before the National Sanitation Campaign in 2011}

In the past, sanitation was stigmatised and not regarded as an important subject for anyone. The isolated and uncoordinated project-based sanitation interventions run by the government and development agencies failed to sensitise communities, scale up sanitation, or control sanitationrelated mortality and morbidity.

For example, tragic episodes of diarrhoea and cholera outbreaks in 2009 due to faecal contamination of water in the western part of the country killed some 400 people. People progressively realised that their family members, kin groups, neighbours, and community were being killed in front of their eyes due to poor hygiene and sanitation caused by rampant open defecation.

Prior to the 2011 national sanitation campaign, the WASH sector in Nepal was characterised by fragmentation, duplication, and double-counting due to uncoordinated activity among various actors (MPPW 2011). Planning and programming were patchy, stakeholders lacked a consolidated target of toilet coverage at village development committee/municipality level and at district level. Also, there was no breakdown of national targets into local-level planning and targets (Government of Nepal 2011).

Similarly, the uneven pace and progress of sanitation improvements among various segments of 
communities and districts (e.g. 10.57 per cent households in Bajura district compared to 93.77 per cent households in Kathmandu district in 2010) was one of the biggest challenges. The age-long practice of subsidies had created a big hindrance to sanitation development by killing the capacity, confidence, creativity, and zeal of individuals and communities. Pipes, pans, and pennies were seen as the panacea of sanitation development so that advocacy, awareness, education, and mass sensitisation activities were nominal and confined to only a few communities. The responsibility of sanitation development was shouldered only by the WASH sector stakeholders. This constrained opportunities to leverage the huge resources and efforts of the other development sectors.

\section{Motivating factors in the lead up to National Sanitation Campaign}

The sanitation coverage across Nepal was just 2 per cent in 1980. The International Drinking Water Supply and Sanitation Decade (IDWSSD) was launched from 1981 to 1990 to draw the attention of the global communities. In Nepal, the cumulative impact of IDWSSD, school- and communityled total sanitation approaches, and national- and global-level advocacy campaigns, coupled with the enabling environment created by Millennium Development Goal framework, the South Asian Conference on Sanitation, and the International Year of Sanitation in 2008, paved a robust foundation for establishing sanitation as a key agenda in the national development framework and ensuring additional resources for sanitation.

The direct experience of the community and stakeholders, coupled with flow of field-based reporting by mass media on the reduction of diarrhoea and cholera outbreaks, enabled them to comprehend the values of sanitation for health, dignity, development, social transformation, and prosperity. The Nepalgunj Commitment and Surkhet Declarations on Sanitation (2010) made by cross-sector stakeholders just after the cholera outbreaks in the region triggered a sanitation campaign in the entire western part of the country and beyond. It led to a comprehensive and accelerated sanitation and hygiene campaign.

In 2007, country-level advocacy on drinking water and sanitation as a fundamental right led to recognition of the right to live in a clean and healthy environment in the Interim Constitution of Nepal (2007). In 2008, CSOs appealed to the prime minister of Nepal to prioritise sanitation in national development, which later became one of the key drivers to seek political commitment and formulate the Master Plan. These national-level initiatives triggered politicians to address issues of sanitation and open defecation in their election manifestos.

\section{The 2011 National Sanitation Campaign and Master Plan}

From 2011, the national sanitation campaign was promoted systematically with the enforcement of the Master Plan, which powered nation-wide sanitation actions to awaken communities and unified several streams of stakeholders to mainstream their efforts and resources. The clear sanitation objective, common national goal, well-defined targets, shared responsibilities of stakeholders, and clear roadmap of the Master Plan ignited the campaign. The activation of national- and subnational-level multi-sector coordination mechanisms facilitated the start of a nation-wide sanitation campaign. The Master Plan played an instrumental role in promoting the campaign by coordinating all organisations.

The sanitation campaign in Nepal grew into a mega form of unified promotional activities on sanitation and hygiene powered by the leadership of the government, in partnership with development agencies and communities. The campaign aimed to end open defecation and achieve nationaland sub-national-level sanitation targets in an inclusive, collaborative, and accelerated manner. Ultimately, each community and district accepted improved sanitation as a matter of its self-respect and prestige too.

Campaign activities included (Adhikari 2015 and NSHCC 2020):

- The conduction of community- and school-level rallies and processions.

- Songs, dance, and street drama.

- A sanitation mega festival (e.g. in Bandipur in Tanahun district in 2008). 
- Mass handwashing with soap events (e.g. in Chitwan district in 2011).

- Charity fund collection programme to support ultra-poor communities (e.g. in Sunsari district).

- Cross-community observation visits.

- Display of sanitation stalls.

- Declaration of sanitation champions.

- Public praise of sanitation promoters.

These activities were all integral components of the campaign. They had a large influence on locallevel motivation, monitoring, and learning, and ultimately enabled Nepal to achieve ODF status by 2017 as outlined in the Master Plan.

The Constitution of Nepal (2015) held that every citizen shall have the right of access to safe water and sanitation. Ministerial participation in the South Asian Conference on Sanitation further reinforced political commitments for sanitation. The extensive discussions, continuous follow up, and increasing practice of sanitation and hygiene created a sense of healthy competition among communities, local governments, and districts. Likewise, emotionally charged slogans like 'I feel pride having toilet in my home' and the activation of community's dignity to end age long practices of open defecation added further energy and momentum to the nation-wide campaign. The campaign was strengthened by a number of supportive factors (Box 1).

\title{
Box 1: Factors strengthening the sanitation campaign
}

\author{
Increased sanitation funds
}

- WASH sector policies provisioned for $20 \%$ of the water supply and sanitation budget to be allocated to sanitation (MPPW 2004).

- The matching fund model leveraged significant local government resources and helped set a trend for sustained financing for the sanitation sector. For example, under the Global Sanitation Fund programme, close to USD 2 million was leveraged across 726 village development committees (VDCs) between 2010 and 2018. Approximately two-thirds of contributions were made by VDCs. The matching fund mechanism is an important success factor for the programme and was replicated by other development partners supporting the Terai sanitation campaign (WSSCC 2019). The funds were used extensively for monitoring and verification.

Increased sanitation programming

- Nationwide expansion of standalone sanitation programmes and the launch of sanitation-dedicated programmes contributed to fulfil local targets and scale up the ODF campaign.

- The launch of an intensive sanitation mission in the Terai aroused stakeholders and communities to run ODF processes and achieve locally set milestones and targets.

- The no-subsidy campaign re-vitalised communities' strengths for collaborative action, while local governments supported locally identified poor and marginalised people.

Increased political commitment

- Recognition given to sanitation within an election manifesto made political parties accountable and also ensured active participation of local- to high-level politicians in the campaign.

- The participation of dignitaries in the ODF campaign put sanitation in the limelight. For 
example, the prime minister declared Kaski as the first ODF district in the country in 2011 and the president formally declared Bhaktapur as an ODF zone at the 5th South Asian Conference on Sanitation held in Nepal in 2013.

\section{Cross-sector involvement}

- Policies and activities of cross-sector development such as education, health, women and children, and local development recognised ODF status as a key development agenda, and contributed to fill the resource gap.

\section{Behaviour change campaigns}

- Popularisation of the National Sanitation and Hygiene Coordination Committee (NSHCC's) statement titled 'Open defecation is a social crime', published in the national daily press and widely shared during national- and sub-national-level sanitation conferences and strategic planning workshops, enabled local government, wards, and communities to enforce local-level social codes of conducts to curb open defecation.

- Sectortriggering enabled broad-based alliances, wider sectoral linkages, comprehensive planning, effective community mobilisation, massive resource pooling arrangements, and wider political mobilisation stimulated the campaign to scale up in an accelerated manner (Adhikari 2015).

\section{Media engagement}

- CSO's advocacy efforts and the continuous media mission enabled aggressive monitoring, follow-up, and reporting activities. Independent reporting in the mass media helped maintain transparency.

- Reporting on the gradual reduction in diarrhoeal diseases increased people's attention to the ODF campaign.

\subsection{Design of the campaign}

The country's much awaited aspiration to achieve ODF status was the basis of the campaign. The combination of national commitment and local actions added energy to it. District and local governments prioritised sanitation because their policy and planning documents made them responsible for achieving their ODF target. For example, the Environment Friendly Local Governance Framework 2013 had established ODF status as a key agenda item in district and local level plans. The WASH Coordination Committees (WASH-CCS), a decentralised coordination mechanism, led to the establishment of an evidence-based target and campaign.

\section{Participatory planning and design}

Nepal's sanitation campaign was designed through a bottom-up participatory planning approach by engaging a wide range of stakeholders, including media and CSOs, in formulating district and local level strategic plan/plan of action on sanitation. The strategic plan/plan of action on sanitation which set out the sanitation status, stakeholders, resources, targets, milestones, approaches, and strategies was the basis of the campaign and the subsequent joint-monitoring processes. This stakeholders' joint plan (also called 'the basket plan') enabled the pooling of cross-sector resources. The media and CSOs were provided with financial incentives and transportation costs during their engagement in planning, monitoring, and reporting processes.

The following guiding principles of the Master Plan were the overarching principles for designing the campaign: 
- ODF status as the bottom line of all sanitation interventions.

- Universal access to sanitation in water supply and sanitation project areas.

- Informed technology choices for household toilets.

- $\quad$ Leadership of the local government.

- VDC/municipality as the basic unit of programme intervention.

- Locally managed financial support mechanisms.

- Sanitation facilities in institutions.

- Mandatory provision of toilets in new buildings and their regular maintenance.

- Hand washing with soap and other hygiene behaviours.

Although the VDC/municipality level was recognised as the basic unit of the sanitation programme, the ODF campaign was run gradually from small communities, toles, school catchments areas, and wards.

The ward - and community - level plan of action were highly important to:

- $\quad$ Build community ownership.

- Develop local leadership.

- Enforce a social code of conduct.

- $\quad$ Generate data through community-level base line survey/social mapping.

- Undertake self-monitoring based on locally set target and indicators.

The ODF status sustainability study of 2016 and 2017 recommended that self-monitoring should be established as a social norm at schools and villages through schools and WASH-CCs (NSHCC 2016 and UN-Habitat 2017).

\subsection{Setting (and (re)setting) targets for campaigns}

Under the national sanitation campaign, a favourable political environment and WASH-sector policies enabled the government to design and set national and sub-national targets. Sanitation targets were defined in terms of universal access to a toilet and maintenance of ODF status. The Master Plan set a national target of becoming ODF by 2017, with three milestones in terms of coverage of household toilets: 60 per cent by 2012/13, 80 per cent by 2014/15 and 100 per cent by 2016/17. These targets and milestones were based on primary data produced by the National Information Management Project (NMIP)/National Information Management System of the then Department of Water Supply and Sewerage (DWSS), trends of toilet promotion in households, and ODF declaration in the district.

At the local level, milestones were set by districts. Although district and local governments do not include elected political representatives, they ensured the commitment of a multi-party mechanism for allocating additional resources to speed up the roll out of the sanitation campaign.

The then Steering Committee for National Sanitation Action and WASH-CCs set the national - and sub-national - level targets respectively. Municipality, rural municipality, and the then VDC-level targets were set by considering respective district level targets. Ward-level targets were set in turn. The data obtained from baseline surveys and field monitoring was crucial to assess the ground reality and to set evidence-based targets. Baseline data was collected prior to formulation of the strategic plan/plan of action on sanitation, target setting, and promotional activities. Implementing agencies updated the baseline data from time to time during the ODF campaign and presented it at the progress sharing meeting of the WASH-CCs and stakeholders. The data thus produced was documented/updated by the secretariat of the WASH-CCs. The data provided to the secretariat of the National Sanitation and Hygiene Coordination Committee (NSHCC) by district WASH-CCs was 
integrated with the NMIP through their own reporting process.

Issues such as demand and supply of non-local sanitation materials, festival and farming seasons, and the school academic calendar were considered while setting the target. Sanitation conferences, reviews, and strategic planning workshops were the major avenues to design the campaign at district and local level. The discussions held during strategic planning workshops comprised a review and analysis of status (coverage and functionality of toilets and the availability of water), challenges (institutional, financial, and behavioural) and opportunities (human and financial resources). While deciding on a target, a vigorous discussion often took place among stakeholders with counter arguments. The issues raised by community members and the media, as well as findings from field monitoring, were widely discussed during the sanitation conferences.

For the target setting process, sanitation task forces/technical groups were engaged to verify the field situation and recommend an evidence-based target, which was later discussed and endorsed through consensus in a joint meeting of WASH-CCs, governmental and non-governmental organisations, a network of forest and water users' committees, CSOs, academia, and the media.

There were a few instances of target amendments. The WASH-CCs of the earthquake and flood-affected districts reset their targets. For example, the sanitation targets for Saptari, Siraha, Dhanusha, Mahottari, Sarlahi, Bara, Rautahat, and Parsa districts were amended following vigorous discussion among members of WASH-CCs, cross-sector stakeholders, political leaders, civil society organisations, and the media. The targets in these districts were heavily affected by impediments in cross-border mobility, difficulties in transportation of sanitation materials caused by fuel crises, the flood of 2016, and anomalous situations during local elections and the state's federalisation. The NSHCC had thus intensified technical backstopping to districts and local governments had mobilised their resources to support needy households and restore the situation.

Setting national - and local-level ODF targets created a positive pressure (Shrestha et al. 2018). However, district - and local-level targets were not imposed by the national government but rather largely guided by the national target and the realities on-the-ground. The NSHCC in collaboration with UNICEF Nepal had undertaken an ODF sustainability study in 2016 (NSHCC 2016) to ascertain if ODF status was being retained in communities. Considering this study's findings, the central, district, and local level monitoring activities were intensified to mitigate challenges along with the provision of support packages to ultra-poor people, massive community sensitisation activities through sector triggering, engagement of commandos to support people with disabilities, and enforcement of social code of conducts. Several communities were visited and rigorous progress sharing/micro-planning workshops were held to address regression in ODF-declared areas.

In order to sustain ODF status and promote sustainable hygiene behaviours, the government had introduced a total sanitation intervention in 2012 and also enforced Total Sanitation Guidelines in 2017. This study and a similar sustainability study carried out by the Global Sanitation Fund programme/UN-Habitat Nepal in 2017 helped to diagnose challenges/regressions and frame locally appropriate interventions in the following days (UN-Habitat 2017).

Nepal's sanitation campaign offered opportunities for people to raise their grievances about targets and ODF declaration. For example they could:

- $\quad$ Float opinion through social media (Facebook).

- Share feelings with members of 'monitoring' and 'verification monitoring' teams.

- Express opinion about transparency and budget mobilisation/expenditure in social audit processes run in the water supply and sanitation project areas.

- $\quad$ Sometimes raise voices during ODF verification and declaration ceremonies.

For example, it was found during monitoring visits that some community members including women in the then Thakurdwara VDC in Bardiya district had raised their voices against the VDC secretary (chairperson of V-WASH-CC) not to declare the VDC as an ODF zone before ascertaining the 'use of toilets' by all and 'no open defecation' within the VDC area. There was no dedicated grievance redressal mechanism with district and local level coordination mechanisms like in water supply and sanitation project works. However, if WASH-CCs, especially at local level, found lapses in the 
use of toilets, they took immediate action to address the shortcomings due to their proximity and day-to-day interaction with community members. If they found poor/disadvantaged and disasteraffected people without access to a toilet, they provided financial and material support, ran training on facilitating behavioural change, communication/triggering activities and intensified monitoring activities in collaboration with development partners. If well-off people were practising open defecation, the social code of conduct, like use of sanitation card, was enforced to discourage this malpractice.

Nepal's sanitation milestones and targets as envisaged by the Master Plan remained realistic. The data showed that the country had achieved:

- Milestone 1) Target of 60 per cent coverage by 2012/13: 62 per cent coverage was achieved.

- Milestone 2) Target of 82 per cent target by 2014/15: 81 per cent coverage was achieved.

- Milestone 3) Target of 100 per cent target by 2016/17: 87 per cent coverage was achieved.

This provides evidence that national level achievements against the set target and milestones remained very close to reality, except in the third milestone, despite the above-mentioned hardships. For a place to gain ODF status, all households in a designated area had to have access to a toilet and no traces of faeces found at any time.

\section{Stakeholders in the campaign}

The wide range of stakeholders gave a strong thrust to the sanitation campaign. The national and sub-national level coordination mechanisms were formed and institutionalised by uniting a wide range of stakeholders from government and non-government sectors and representing WASH, health, education, women and children, local development, media, and CSOs. This institutional arrangement provided opportunities for all sector actors to fulfil their overall sanitation target in the district and local level through basket planning, cost sharing, and resource pooling arrangements, even if any individual organisation was unable to fulfil its target on its own resources. For example, under rural sanitation intervention, development agencies in Nepal often contributed to software aspects of sanitation (institutional strengthening, advocacy, and capacity development), which were complemented by local government in hardware aspects (promotion of physical facilities of WASH) for poor/marginalised households and also for schools.

There were contributions to sanitation from all concerned sectors.

- The political sector contributed to policy formulation.

- The WASH sector managed technology and budget.

- The education sector expanded knowledge and skills.

- Women and children advocated issues around children and gender.

- The general administration and security sector enforced legal provisions.

- Media and civil society triggered stakeholders and aired the pressing issues of sanitation.

- Teachers, students, and child clubs influenced parents.

- Religious leaders promoted sanitation in socio-cultural festivals and occasions.

- Forest user groups provided wood for construction to needy households.

- The private sector supplied loans and sanitation materials.

'Triggerers' and the health sector revealed the impacts of improved sanitation on public health and persuaded communities. The sanitation commandos extended their support by building toilets for people with disabilities. The Daanveer (philanthropists) provided money and land to needy households. On top of that, communities mobilised their massive resources to construct household 
toilets and enforce local norms and a code of conduct (e.g. to stop defecation in open places, wash hands at critical times, and stop throwing away plastic products in public places and across roads). The national and sub-national level cross-sector institutional arrangement/coordination mechanism systematically unified a wide range of stakeholders and synergised their efforts. So, the sanitation for all (dream) and all for sanitation (strategy) was well grounded in the national sanitation campaign in Nepal.

\subsection{Incentives and sanctions for monitoring, reporting, and honest feed back in the ODF campaign}

Figure 1: Map of Nepal

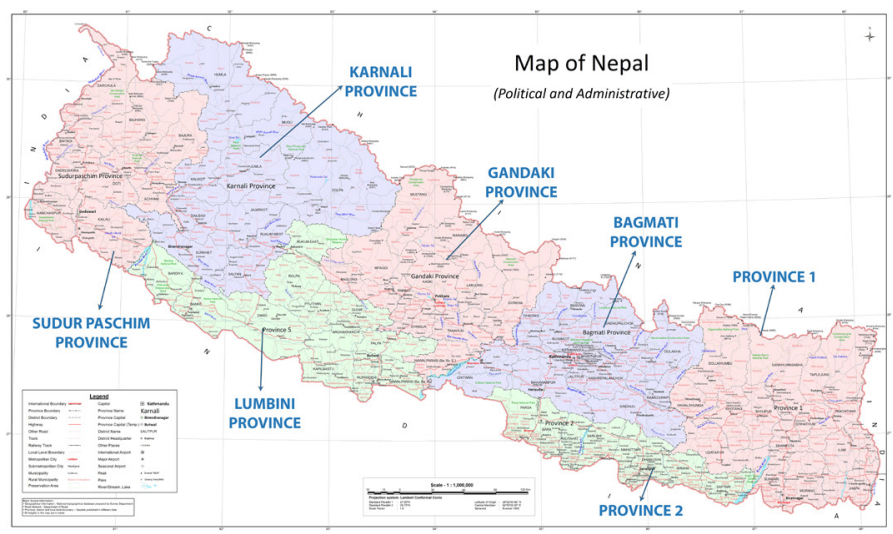

Source: Government of Nepal. Ministry of Land Management, Cooperatives and Poverty Alleviation, Survey Department
The secretariat of the NSHCC showed that sanitation coverage was 95 per cent until 2017. It was 99.02 per cent in 2018 , and increased to 99.5 per cent by June of 2019. Altogether 35,776 household toilets had to be built at that time. Of these, Province No. 2 (Fig. 1) alone had to build 25,000 toilets. A total of 11 districts including a few hilly districts and many Terai districts had to become ODF. The southern strip of Terai districts lagged behind and were recognised as the final hurdle to move the campaign forward (WSSCC 2019). In response site-specific and tailormade approaches were adopted.

Monitoring was intensified in the Terai and other communities to identify if toilets promotion was hampered due to people's personal inability, lack of awareness, or lack of willingness. For example, there were several instances where even well-off persons with expensive watches, mobile phones, televisions, and motorbikes did not possess toilets in their households as they were habituated to defecating on the bank of water bodies and across the foot trail/road. On the other hand, people in earthquake-affected districts, for example in Sindhupalchowk, had given first priority to repairing their demolished toilets.

The NSHCC had, therefore, taken a special step to intensify monitoring to closely assess the ground reality, revisit targets and deadlines, and to respond to the earthquake and flood affected Terai districts. For example, it conducted the Terai Conference on Sanitation and inter-district extended workshop of WASH-CCs, and also engaged media, members of NSHCC, and national level special team of WASH professionals (Monitoring and Action Team-MAT) to frequently monitor community level promotional activities, report/share field findings with local and district level stakeholders, and backstop them to take proper intervention for addressing the issues and achieving the target in collaboration.

WASH-CCs also conducted their meetings in those communities (especially in Terai districts) where people were found defecating in open places. Local-level volunteers commissioned morning and evening patrolling and weekly encampment campaign activities there. The 'sanitation military' (a group of local level volunteers) engaged in monitoring activities, digging out practical problems/ constraints, sensitising communities, and providing locally collected donations for poor households in Sunsari district, for example. In some places, for example in Dang district, local communities had chased out the monitoring team, while in Rautahat district a women's group had protested against the team for insulting them as open defecators. Such monitoring visits helped curb open defecation by conducting door-to-door visit by WASH-CCs and community sensitisation activities; providing support to poor households to upgrade toilets, and enforcing social sanctions and the code of conduct. 
On the occasion of a district ODF declaration, each district publicly announced the implementation of total sanitation with the sole aim to retain ODF status and move up the sanitation ladder. So, local level facilitators and triggerers were widely engaged in field monitoring to check shortcomings and engage local governments and wards for corrective actions. However, such monitoring was more oriented towards speeding up ODF declarations when the districts were close to the deadline. The issues of slippages/regressions as identified through ODF sustainability studies were widely discussed in the NSHCC meetings and intensified progress review meetings, microplanning workshops, and field monitoring to address challenges took place, especially in the Terai districts.

\section{$5 \quad$ Monitoring Systems}

The Master Plan emphasised at national and sub-national level the need for monitoring in order to achieve and sustain ODF. It made the NSHCC and WASH-CCs accountable to lead monitoring, verification, and declaration of ODF status. The taskforce/technical groups were engaged as a technical wing of these coordination mechanisms to support in planning, programming, monitoring, and reporting. The general mechanism and protocol of monitoring was same throughout the country. However, team composition, the size of sample households, and the reporting format were designed in line with local situation and need. Some districts developed a separate monitoring guideline, for example Morang, (Fig.2) to supplement the monitoring mechanism set out in their district level strategic plan/plan of action on sanitation.

Figure 2. Monitoring Guideline in Morang District:

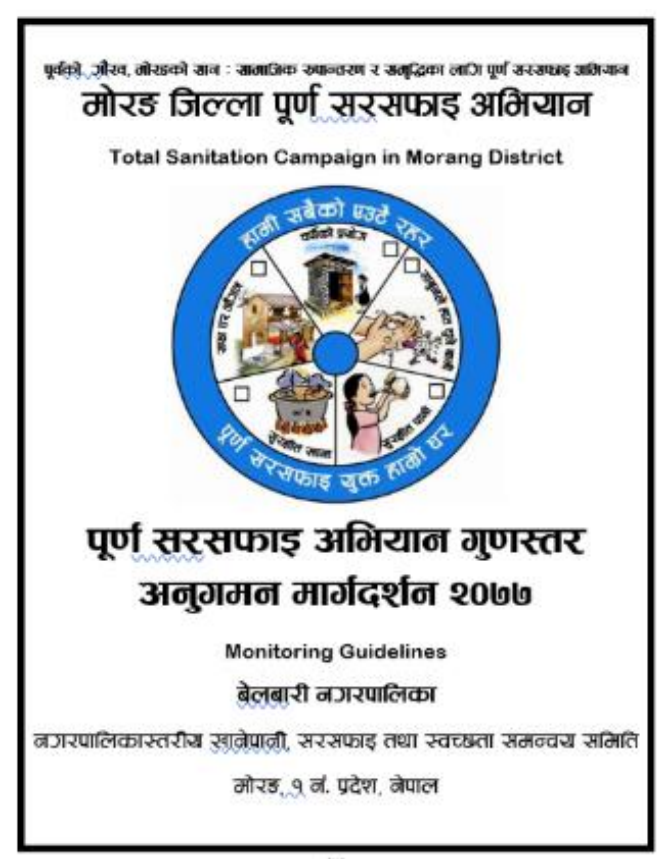

Source: Binod Prasad Sharma, The then District Coordinator, UN Habitat Nepal
In general, if district and local level WASH-CCs failed to achieve the envisaged result, the NSHCC took immediate steps to conduct a joint meeting of its representatives, WASH-CCS, media, and CSOs in order to dig out impediments, critically assess the WASH-CC's performance, strategise actions, and publicise the decision through media. For example, such a meeting held in Kapilvastu district in 2018 made ward authorities responsible for intensifying their monitoring in wards and communities and regularly share the achievements in the subsequent meetings of district and local level WASH-CCS. This participatory progress assessment process, the possibility of being criticised for poor performance, and the recognition given to the best performers, are key elements that led to establishing ownership of, responsibility, and accountability for the coordination mechanisms. But no penalty system existed for poor performance. The secretariat of the NSHCC and WASH-CCs facilitated overall monitoring and reporting. The monitoring team used the standard format, tools, and monitoring guidelines and conducted monitoring in the designated area considering the socio-economic, cultural, and geographical attributes of the communities.

In order to make monitoring free from prejudice, works undertaken by implementing agencies was cross-checked by three different sources: WASH-CC's regular community level monitoring; a crossVDC/municipality study visit; and a joint sector review (JSR) learning visit. For example, the JSR learning visit team studied several water supply project areas and ODF-campaign-related activities, and documented learnings in the WASH Sector Status Report 2011. Such study/learning visits enabled critical assessment of the field situation, independent feedback to WASH-CCs, stakeholders, programme executing agencies, programme implementing agencies, and communities, and lessons for the betterment of WASH sector activities. 


\section{Participatory monitoring}

The process of monitoring was participatory at all levels. The role of monitoring was instrumental to activate community members to build and use toilets and adopt proper hygiene behaviours.

Field level monitoring took place at two levels:

- Monitoring carried out by support organisations/implementing agencies was further monitored by WASH-CCs during field monitoring.

- Monitoring carried out by WASH-CCs was monitored by one higher level WASH-CC during verification monitoring.

The cross-monitoring thus contributed to checks and balances and showed the actual field reality transparently and without bias. Joint monitoring teams comprised members from crosssector government and non-government organisations as well as the media, with equal gender representation. They were led by government officials but all team members were recognised on an equal footing. By virtue of its heterogenous composition and standard monitoring protocol, the monitoring team members inevitably remained impartial while assessing the field situation and forwarding evidence-based recommendations to concerned WASH-CCs. Joint monitoring identified whether there was over reporting, false reporting, and non-transparency in programme processes.

Unlike monitoring of physical facilities, quality monitoring (monitoring of quality aspects) observed and assessed whether key behaviours such as the safety and cleanliness of toilets, the practise of defecation in toilets, retention of ODF status in designated areas, and hand washing with soap at critical times were maintained. Such monitoring was widely applied in Arghaknahchi, Jhapa, and some other Terai districts. The quality monitoring remained instrumental to identify/check regressions after ODF declaration.

The monitoring report was prepared, shared, and discussed in a transparent way at a meeting of the NSHCC and WASH-CCs. At central and district level, there was collaboration with media to launch a countdown for monitoring and expediating the campaign. The data/information obtained from monitoring and issues raised by mass media were also an important basis to identify challenges and driving forces, redesign the campaign, and intensify actions for envisaged results. WASH-CCs recognised field monitoring as an important planning and decision-making tool to strategise the campaign based on the ground reality. The overall monitoring system of the campaign is presented in Table 2.

Table-2: Campaign Monitoring System: Stakeholders and Role

\begin{tabular}{|c|c|c|c|c|c|}
\hline \multirow[t]{2}{*}{ THEMES } & \multicolumn{5}{|c|}{ MONITORING STAKEHOLDER AND ROLE } \\
\hline & $\begin{array}{l}\text { NSHCC, WASH-CCS AND TASK } \\
\text { FORCE }\end{array}$ & $\begin{array}{l}\text { JSR LEARNING } \\
\text { VISIT TEAM }\end{array}$ & $\begin{array}{l}\text { PROGRAMME } \\
\text { EXECUTING AND } \\
\text { IMPLEMENTING } \\
\text { AGENCIES }\end{array}$ & MEDIA & $\begin{array}{l}\text { INDEPENDENT } \\
\text { RESEARCHERS }\end{array}$ \\
\hline $\begin{array}{l}\text { Monitoring } \\
\text { team }\end{array}$ & $\begin{array}{l}\text { Monitoring team of NSHCC } \\
\text { and WASH-CC was led by } \\
\text { government officials and } \\
\text { comprised 7-9 members } \\
\text { representing WASH- } \\
\text { CCs, media, civil society } \\
\text { organisations and user } \\
\text { committees, considering the } \\
\text { gender and expertise of its } \\
\text { members. }\end{array}$ & $\begin{array}{l}\text { Cross-sector } \\
\text { agencies } \\
\text { comprising 5-7 } \\
\text { members }\end{array}$ & Focal person & $\begin{array}{l}\text { Person dealing } \\
\text { WASH sector } \\
\text { issues }\end{array}$ & Professional \\
\hline $\begin{array}{l}\text { Monitoring } \\
\text { tools }\end{array}$ & $\begin{array}{l}\text { - Checklist } \\
\text { - Monitoring format } \\
\text { - Sanitation card } \\
\text { - Observation }\end{array}$ & $\begin{array}{l}\text { - Checklist } \\
\text { - Monitoring } \\
\text { format } \\
\text { - Observation }\end{array}$ & $\begin{array}{l}\text { - Checklist } \\
\text { - Monitoring } \\
\text { format } \\
\text { - Observation }\end{array}$ & $\begin{array}{l}\text { - Checklist } \\
\text { - Observation }\end{array}$ & $\begin{array}{l}\text { - Checklist } \\
\text { - Monitoring } \\
\text { format } \\
\text { - Observation }\end{array}$ \\
\hline
\end{tabular}




\begin{tabular}{|c|c|c|c|c|c|}
\hline \multirow[t]{2}{*}{ THEMES } & \multicolumn{5}{|l|}{ MONITORING STAKEHOLDER AND ROLE } \\
\hline & $\begin{array}{l}\text { NSHCC, WASH-CCS AND TASK } \\
\text { FORCE }\end{array}$ & $\begin{array}{l}\text { JSR LEARNING } \\
\text { VISIT TEAM }\end{array}$ & $\begin{array}{l}\text { PROGRAMME } \\
\text { EXECUTING AND } \\
\text { IMPLEMENTING } \\
\text { AGENCIES } \\
\end{array}$ & MEDIA & $\begin{array}{l}\text { INDEPENDENT } \\
\text { RESEARCHERS }\end{array}$ \\
\hline $\begin{array}{l}\text { Monitoring } \\
\text { avenues }\end{array}$ & $\begin{array}{l}\text { - Monitoring } \\
\text { - Verification monitoring } \\
\text { - Validation workshop } \\
\text { - Sanitation conference } \\
\text { - Cross-district/cross- } \\
\text { municipality/cross-community } \\
\text { visit } \\
\text { - Press meetings }\end{array}$ & - Monitoring & - Monitoring & - Monitoring & - Monitoring \\
\hline $\begin{array}{l}\text { Types of } \\
\text { monitoring }\end{array}$ & $\begin{array}{l}\text { - Process monitoring assesses } \\
\text { proactiveness of WASH- } \\
\text { CCs and implementing } \\
\text { agencies, formulation and } \\
\text { implementation of strategic } \\
\text { plan/plan of action, capacity } \\
\text { development of stakeholders, } \\
\text { financial inputs, and } \\
\text { community sensitisation/ } \\
\text { empowerment. } \\
\text { - Outcome monitoring focuses } \\
\text { on construction and use of } \\
\text { toilets, hand-washing stations, } \\
\text { and maintenance of ODF } \\
\text { status. } \\
\text { - Quality monitoring focused } \\
\text { on monitoring of behavioural } \\
\text { aspects. } \\
\text { - Joint-monitoring was carried } \\
\text { out by cross-sector team. }\end{array}$ & $\begin{array}{l}\text { - Process } \\
\text { monitoring } \\
\text { - Outcome } \\
\text { monitoring }\end{array}$ & $\begin{array}{l}\text { - Process } \\
\text { monitoring } \\
\text { - Progress } \\
\text { monitoring } \\
\text { - Outcome } \\
\text { monitoring } \\
\text { - Self- } \\
\text { monitoring } \\
\text { was carried } \\
\text { out in their } \\
\text { programme } \\
\text { areas. }\end{array}$ & $\begin{array}{l}\text { - Outcome } \\
\text { monitoring }\end{array}$ & $\begin{array}{l}\text { - Process } \\
\text { monitoring } \\
\text { - Progress } \\
\text { monitoring } \\
\text { - Outcome } \\
\text { monitoring }\end{array}$ \\
\hline $\begin{array}{l}\text { Levels of } \\
\text { monitoring }\end{array}$ & $\begin{array}{l}\text { - Communities were monitored } \\
\text { by ward level WASH-CCs. } \\
\text { - Ward areas were monitored } \\
\text { by VDC, municipality and rural } \\
\text { municipality WASH-CCs. } \\
\text { - VDC, rural municipality and } \\
\text { municipality areas were } \\
\text { monitored by district WASH- } \\
\text { CCs. } \\
\text { - District areas were monitored } \\
\text { by province WASH-CCS (or } \\
\text { the then regional WASH-CC). }\end{array}$ & $\begin{array}{l}\text { - Monitoring } \\
\text { of overall } \\
\text { activities } \\
\text { facilitated by } \\
\text { WASH-CCs, } \\
\text { executing } \\
\text { agencies, and } \\
\text { implementing } \\
\text { agencies }\end{array}$ & 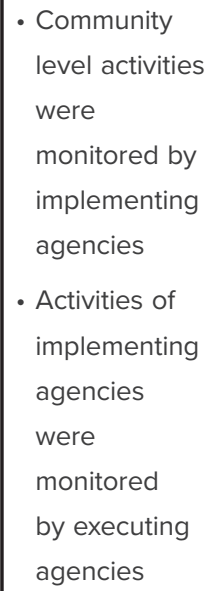 & $\begin{array}{l}\text { - Monitoring } \\
\text { of overall } \\
\text { activities }\end{array}$ & $\begin{array}{l}\text { - Monitoring of } \\
\text { overall activities }\end{array}$ \\
\hline
\end{tabular}




\begin{tabular}{|c|c|c|c|c|c|}
\hline \multirow[t]{2}{*}{ THEMES } & \multicolumn{5}{|c|}{ MONITORING STAKEHOLDER AND ROLE } \\
\hline & $\begin{array}{l}\text { NSHCC, WASH-CCS AND TASK } \\
\text { FORCE }\end{array}$ & $\begin{array}{l}\text { JSR LEARNING } \\
\text { VISIT TEAM }\end{array}$ & $\begin{array}{l}\text { PROGRAMME } \\
\text { EXECUTING AND } \\
\text { IMPLEMENTING } \\
\text { AGENCIES }\end{array}$ & MEDIA & $\begin{array}{l}\text { INDEPENDENT } \\
\text { RESEARCHERS }\end{array}$ \\
\hline $\begin{array}{l}\text { Sample } \\
\text { size }\end{array}$ & $\begin{array}{l}\text { - Ward-level WASH-CCs } \\
\text { monitored } 100 \% \text { households } \\
\text { in its communities. } \\
\text { - VDC, rural municipality, } \\
\text { and municipality WASH- } \\
\text { CCs monitored 10-20\% } \\
\text { households in their ward. } \\
\text { - District WASH-CCs monitored } \\
\text { 10-20\% households in } \\
\text { VDC, rural municipality and } \\
\text { municipality area. }\end{array}$ & $\begin{array}{l}\text { - A few } \\
\text { representative } \\
\text { samples }\end{array}$ & $\begin{array}{l}\text { - Majority of } \\
\text { households }\end{array}$ & $\begin{array}{l}\text { - Entire } \\
\text { households }\end{array}$ & $\begin{array}{l}\text { - Statistically } \\
\text { significant } \\
\text { sample size }\end{array}$ \\
\hline $\begin{array}{l}\text { Aspects of } \\
\text { monitoring }\end{array}$ & $\begin{array}{l}\text { - Quantitative and qualitative } \\
\text { aspects of sanitation. } \\
\text { - Use of household and } \\
\text { institutional toilets. } \\
\text { - Provision of hand washing } \\
\text { facilities and practice. } \\
\text { - Availability of water in toilets. } \\
\text { - Waste management. } \\
\text { - State of open defecation. } \\
\text { - Personal hygiene and } \\
\text { sanitation. }\end{array}$ & $\begin{array}{l}\text { - Often all } \\
\text { aspects as } \\
\text { monitored } \\
\text { by NSHCC, } \\
\text { WASH-CCs, } \\
\text { and taskforce }\end{array}$ & $\begin{array}{l}\text { - Based on } \\
\text { indicators } \\
\text { defined by } \\
\text { project/ } \\
\text { programme }\end{array}$ & $\begin{array}{l}\text { - Often all } \\
\text { aspects as } \\
\text { monitored } \\
\text { by NSHCC, } \\
\text { WASH-CCs }\end{array}$ & $\begin{array}{l}\text { - As designed } \\
\text { by research } \\
\text { questions }\end{array}$ \\
\hline $\begin{array}{l}\text { Process of } \\
\text { monitoring } \\
\text { by WASH- } \\
\text { CC }\end{array}$ & $\begin{array}{l}\text { - Step-1: Identification of } \\
\text { monitoring area. } \\
\text { - Step-2: Coordination with } \\
\text { stakeholders of the area. } \\
\text { - Step-3: Meeting of monitoring } \\
\text { team members. } \\
\text { - Step-4: Preparation of } \\
\text { monitoring checklist/format. } \\
\text { - Step-5: Field visit and } \\
\text { discussion of monitoring } \\
\text { team with stakeholders and } \\
\text { community members. } \\
\text { - Step-6: Collection of field } \\
\text { data and information. } \\
\text { - Step-7: Preparation of } \\
\text { monitoring report. } \\
\text { - Step-8: Submission of report } \\
\text { to respective coordination } \\
\text { mechanism. } \\
\text { - Step-9: Joint meeting of } \\
\text { coordination mechanism and } \\
\text { monitoring team for decision } \\
\text { on further actions. }\end{array}$ & $\begin{array}{l}\text { Often all steps } \\
\text { up to step } \\
7 \text { adopted } \\
\text { by NSHCC, } \\
\text { WASH-CCs, } \\
\text { and taskforce. }\end{array}$ & $\begin{array}{l}\text { - As per } \\
\text { agency's own } \\
\text { monitoring } \\
\text { framework }\end{array}$ & $\begin{array}{l}\text { - As designed } \\
\text { independently }\end{array}$ & $\begin{array}{l}\text { - As designed } \\
\text { by research } \\
\text { methodology } \\
\text { and protocol }\end{array}$ \\
\hline
\end{tabular}




\begin{tabular}{|c|c|c|c|c|c|}
\hline \multirow[t]{2}{*}{ THEMES } & \multicolumn{5}{|c|}{ MONITORING STAKEHOLDER AND ROLE } \\
\hline & $\begin{array}{l}\text { NSHCC, WASH-CCS AND TASK } \\
\text { FORCE }\end{array}$ & $\begin{array}{l}\text { JSR LEARNING } \\
\text { VISIT TEAM }\end{array}$ & $\begin{array}{l}\text { PROGRAMME } \\
\text { EXECUTING AND } \\
\text { IMPLEMENTING } \\
\text { AGENCIES }\end{array}$ & MEDIA & $\begin{array}{l}\text { INDEPENDENT } \\
\text { RESEARCHERS }\end{array}$ \\
\hline $\begin{array}{l}\text { Challenges } \\
\text { identified } \\
\text { through } \\
\text { monitoring }\end{array}$ & $\begin{array}{l}\text { - Poor and landless lack funds } \\
\text { for toilet construction. } \\
\text { - Lack of micro planning in } \\
\text { Terai districts. } \\
\text { - Ineffective community } \\
\text { sensitisation in Terai due to } \\
\text { engagement of non-local } \\
\text { triggerers. } \\
\text { - Indifference of WASH-CCs } \\
\text { and economically better-off } \\
\text { people. } \\
\text { - Visible hindrance due to } \\
\text { subsidy-seeking attitudes. } \\
\text { - Difficulties in transportation of } \\
\text { non-local sanitation materials } \\
\text { in remote areas. } \\
\text { - Prolonged monitoring due to } \\
\text { geographical difficulties. } \\
\text { mbalance of supply and } \\
\text { demand of sanitation } \\
\text { materials during peak of the } \\
\text { campaign in high population } \\
\text { areas. } \\
\text { - Lack of mission-driven } \\
\text { collaboration with media in } \\
\text { Terai. } \\
\text { - Ineffective penetration } \\
\text { of district WASH-CCs in } \\
\text { metropolitan and sub- } \\
\text { metropolitan areas. } \\
\text { - Inadequate central level } \\
\text { of level. } \\
\text { - }\end{array}$ & $\begin{array}{l}\text { - To have better } \\
\text { water and } \\
\text { sanitation } \\
\text { sector } \\
\text { performance, } \\
\text { the sector } \\
\text { needs } \\
\text { functional, } \\
\text { coordinated, } \\
\text { and } \\
\text { harmonised } \\
\text { information- } \\
\text { based } \\
\text { planning and } \\
\text { monitoring } \\
\text { systems }\end{array}$ & $\begin{array}{l}\text { - In line with } \\
\text { agency's } \\
\text { monitoring } \\
\text { objectives }\end{array}$ & $\begin{array}{l}\text { - In line with } \\
\text { media's } \\
\text { monitoring } \\
\text { objectives }\end{array}$ & $\begin{array}{l}\text { - In line with } \\
\text { objective/ } \\
\text { question of } \\
\text { research } \\
\text { agency }\end{array}$ \\
\hline
\end{tabular}




\begin{tabular}{|c|c|c|c|c|c|}
\hline \multirow[t]{2}{*}{ THEMES } & \multicolumn{5}{|l|}{ MONITORING STAKEHOLDER AND ROLE } \\
\hline & $\begin{array}{l}\text { NSHCC, WASH-CCS AND TASK } \\
\text { FORCE }\end{array}$ & $\begin{array}{l}\text { JSR LEARNING } \\
\text { VISIT TEAM }\end{array}$ & $\begin{array}{l}\text { PROGRAMME } \\
\text { EXECUTING AND } \\
\text { IMPLEMENTING } \\
\text { AGENCIES }\end{array}$ & MEDIA & $\begin{array}{l}\text { INDEPENDENT } \\
\text { RESEARCHERS }\end{array}$ \\
\hline $\begin{array}{l}\text { Measures } \\
\text { to mitigate } \\
\text { the issues } \\
\text { identified } \\
\text { through } \\
\text { monitoring }\end{array}$ & $\begin{array}{l}\text { - Provision of local-level } \\
\text { support to disadvantaged } \\
\text { communities, disaster-affected } \\
\text { people, and landless ultra- } \\
\text { poor households. } \\
\text { - Intensive central level } \\
\text { monitoring by MATs as well } \\
\text { as members of NSHCC and } \\
\text { its task force in the district } \\
\text { lagging behind. } \\
\text { - Aggressive media monitoring. } \\
\text { - Collaboration with local ring } \\
\text { producers/suppliers and } \\
\text { masons. } \\
\text { - Cross-district workshop of } \\
\text { WASH-CCs for cross-learning. } \\
\text { - Conduction of district and } \\
\text { municipality level sanitation } \\
\text { conferences for galvanising } \\
\text { cross-sector efforts and } \\
\text { amendment of the deadline } \\
\text { for ODF declaration. }\end{array}$ & $\begin{array}{l}\text { - Broader rec- } \\
\text { ommendations } \\
\text { to the } \\
\text { government }\end{array}$ & $\begin{array}{l}\text { - Correction } \\
\text { as per field } \\
\text { findings }\end{array}$ & $\begin{array}{l}\text { - Recommen- } \\
\text { dation to the } \\
\text { government, } \\
\text { coordination } \\
\text { mechanisms, } \\
\text { executing } \\
\text { agencies, and } \\
\text { implementing } \\
\text { agencies }\end{array}$ & \begin{tabular}{|l} 
- Broader \\
recommenda- \\
tion at policy \\
and operational \\
levels
\end{tabular} \\
\hline $\begin{array}{l}\text { Use of } \\
\text { monitoring } \\
\text { data / } \\
\text { findings }\end{array}$ & $\begin{array}{l}\text { - Revision of national policy } \\
\text { and strategy. } \\
\text { - Formulation of periodic } \\
\text { and annual development } \\
\text { programme. } \\
\text { - Performance evaluation of } \\
\text { support organisations. } \\
\text { - Assess progress and make } \\
\text { decision for future actions. } \\
\text { - Formulation of district and } \\
\text { local level strategic plan. } \\
\text { - Amendment of sanitation } \\
\text { target. } \\
\text { - Verification and ODF/total } \\
\text { sanitation declaration. } \\
\text { - Sector publication. }\end{array}$ & $\begin{array}{l}\text { - Documentation } \\
\text { in JSR report } \\
\text { for policy level } \\
\text { feedback } \\
\text { to the } \\
\text { government }\end{array}$ & $\begin{array}{l}\text { - Documenta- } \\
\text { tion for } \\
\text { betterment of } \\
\text { project }\end{array}$ & $\begin{array}{l}\text { Sharing } \\
\text { for policy, } \\
\text { planning, and } \\
\text { community } \\
\text { level } \\
\text { sensitisation }\end{array}$ & $\begin{array}{l}\text { - Documentation } \\
\text { for further } \\
\text { research and } \\
\text { advocacy }\end{array}$ \\
\hline $\begin{array}{l}\text { Overall } \\
\text { limitations } \\
\text { of } \\
\text { monitoring }\end{array}$ & $\begin{array}{l}\text { - Inadequate human resources } \\
\text { and logistical arrangement } \\
\text { with the secretariat of WASH- } \\
\text { CCs. } \\
\text { - Limited use of information } \\
\text { technology at local levels. }\end{array}$ & $\begin{array}{l}\text { - Limited time } \\
\text { period }\end{array}$ & \begin{tabular}{|l} 
- Lack of \\
dedicated \\
monitoring \\
and \\
evaluation \\
related \\
human \\
resources/ \\
experts
\end{tabular} & $\begin{array}{l}\text { - Limited } \\
\text { logistical } \\
\text { arrangements }\end{array}$ & $\begin{array}{l}\text { - Limited scope } \\
\text { of inquiry }\end{array}$ \\
\hline
\end{tabular}




\section{Verification process}

Verification was recognised as an important step in the sanitation campaign for ensuring the quality and sustainability of ODF status/total sanitation interventions. The verification process sought collective responsibility and accountability of WASH-CCs, support organisations, and implementing agencies for evidence-based declaration and future planning. Sometimes, however, the verification process encountered problems due to prolonged decision-making by province-level WASH-CCs. The WASH-CCs performed the verification process set out in Box 2.

\section{Box 2: Steps of verification}

Step 1: When a designated area has ensured the access of all households to toilets and no open defecation is taking place in the community, schools, and public places, the WASH-CC receives documented data and evidence from the monitoring team. The WASH-CC then verifies and assesses the situation in the field, and holds a WASH-CC meeting to decide on further action.

Step 2: If the WASH-CC is convinced that the designated area is appropriate for ODF declaration, they make a formal decision and submit a letter to the WASH-CC one level higher along with the meeting decision/minutes, photographs of the monitoring process, and data/evidence requesting verification of their area.

Step 3: Following the request, the higher WASH-CC commissions their monitoring team to verify field level activities.

Step 4: The monitoring team discuss the study checklist and prepare monitoring and reporting format.

Step 5: The monitoring team fix the date for verification monitoring.

Step 6: The monitoring team visit purposively selected communities with a set sample size (10-20\% households depending on households' size), interact with community members, observe use, cleanness, and maintenance of toilets and hand-washing behaviours, and ensure there is no faeces in designated places.

Step 7: The monitoring team then discuss their findings with members of the WASH-CC and community leaders. At this stage, community members have an opportunity to openly give their opinion regarding the findings/ODF declaration.

Step 8: The monitoring team return to their work station and collectively discuss field level issues, prepare a report in a prescribed format, and share a field report with the WASH-CC for further action.

Step 9: The WASH-CC then hold a validation meeting (also called a validation workshop) including members of the monitoring team and selected members of the WASH$\mathrm{CC}$ in the monitored.

Step 10: If the WASH-CC is convinced, it issues a letter to the concerned WASH-CC with permission for declaring the area ODF. If the WASH-CC finds a need for further improvement, it informs the WASH-CC accordingly with concrete recommendations for required improvements.

There was a strong mechanism in both joint-monitoring and verification monitoring (internal or governmental or formal) to check inflated numbers or over reporting by implementing agencies and local level WASH-CCs. For example, implementing agencies had to share their programme activities 
and progress categorically in a joint progress review meeting of WASH-CC and stakeholders. In addition, media monitoring (external or independent) reported on-the-ground realities, particularly in problem-ridden districts in the Terai region. The practice of inflated numbers or over reporting, though limited, produced an point of criticism for media and also made the concerned WASH-CCS watchful towards the issue.

Each WASH-CC developed and adopted a standard monitoring and verification protocol, which helped capture and check regression/slippage during monitoring and verification. Monitoring by the JSR learning visit team, WASH-CC, and media and cross-ward monitoring captured regression or slippage. The claimed outputs of one implementing agency on ODF attainment were cross-verified by another entity (WASH-CC), which helped avoid bias. In some places, verification monitoring took place two or more times. It was found that the more rigorously smaller areas (e.g. a ward) were monitored, the fewer data discrepancies were found.

Regular morning and evening patrolling by women's groups, cooperatives, volunteers, and triggerers in open defecation sites also remained effective, particularly to identify slippage in ODF declared areas and curb open defecation in communities. On the occasion of district ODF declaration, many district WASH-CCs made public the strategic plan/concept paper/action plan/commitment letter on total sanitation with a public appeal to address lapses and upgrade facilities and behaviours. This showed the WASH-CC's concern for addressing slippage, retaining ODF status, and sustaining the campaign.

\section{Reporting}

Reporting, knowledge management, and sharing were recognised as an important part of the national sanitation campaign. NSHCC documented overall sectoral learning through its periodic sectoral publications, while WASH-CCs documented overall situation, efforts, learning on sanitation, and future actions in their strategic plan/plan of action or other special publications. The field learning was documented in monitoring and verification monitoring reports. The sectoral reports and learning documents were produced by the secretariat of the NSHCC and WASH-CCs. The overall reporting mechanism was as set out in Table 3.

Table 3: Reporting mechanism

\begin{tabular}{|c|c|c|}
\hline SN & PARTICULARS & DESCRIPTION \\
\hline 1. & Reporting entities & $\begin{array}{l}\text { - NSHCC, WASH-CCs, and Task Force. } \\
\text { - MAT and JSR learning visit team. } \\
\text { - Secretariat of NSHCC and WASH-CCs. } \\
\text { - Support organisations. } \\
\text { - Implementing agencies. } \\
\text { - Media. } \\
\text { - Independent researchers. }\end{array}$ \\
\hline 2. & Reporting line & $\begin{array}{l}\text { - Vertical from subnational level coordination mechanism and agencies to } \\
\text { their respective higher-level entities. } \\
\text { - Horizontal among members of coordination mechanisms. }\end{array}$ \\
\hline 3. & Types of report & $\begin{array}{l}\text { - Implementing agencies produced baseline survey report, event-based } \\
\text { report, progress report, and monitoring reports. } \\
\text { - Support organisations produced progress reports. } \\
\text { - Coordination mechanisms mostly produced reports on monitoring and } \\
\text { verification monitoring. }\end{array}$ \\
\hline
\end{tabular}




\begin{tabular}{|c|c|c|}
\hline 4. & Mode of publication of reports & $\begin{array}{l}\text { - Electronic copy displayed on official website. } \\
\text { - Printed copies distributed with stakeholders. } \\
\text { - Social media (e.g. Facebook). }\end{array}$ \\
\hline 5. & Report sharing mechanism & $\begin{array}{l}\text { - Summary of data/information were documented and displayed in hoarding } \\
\text { boards in public places. } \\
\text { - Support organisations/implementing agencies reported to concerned } \\
\text { WASH-CCs and their funding agencies. } \\
\text { - Ward level data/information were documented at the ward office as well as } \\
\text { at the secretariat of the municipality, rural municipality and VDC WASH-CC. } \\
\text { - Municipality/rural municipality/VDC level data and information were } \\
\text { documented by the respective secretariats and their report was shared } \\
\text { with secretariat of the district WASH-CC. } \\
\text { - The secretariat of the district level WASH-CC prepared a summary of } \\
\text { municipality/rural municipality/VDC level data and shared the report with } \\
\text { the secretariat of the provincial WASH-CC (or the then regional level WASH- } \\
\text { CC) and the NSHCC. } \\
\text { - The NSHCC secretariat shared strategic data/reports with its member } \\
\text { organisations, through the NMIP of the Department of Water Supply and } \\
\text { Sewerage Management, Ministry of Water Supply, and National Planning } \\
\text { Commission. }\end{array}$ \\
\hline 6. & Use of reports & $\begin{array}{l}\text { - Revision of national policy and strategy. } \\
\text { - Formulation of periodic and annual development programme. } \\
\text { - Performance evaluation of support organisations. } \\
\text { - Formulation of district and local level strategic plan. } \\
\text { - Formulation of promotional materials. } \\
\text { - Sector learning. } \\
\text { - Sector publication through NMIP of DWSSM. }\end{array}$ \\
\hline 7. & Overall limitations of reporting & $\begin{array}{l}\text { - Lack of use of information technology in data, information, and report } \\
\text { management at local level. } \\
\text { - Lack of prompt reporting. } \\
\text { - Lack of capacity of independent local level reporters, particularly on } \\
\text { technical matters, often led to misleading information. }\end{array}$ \\
\hline
\end{tabular}

The secretariat of the coordination mechanisms updated the monitoring database and shared the reports with higher level WASH-CCs and the NSHCC in a sequence as stated in Table 3. The local level NGOs/programme implementing agencies directly reported to respective WASH-CCs and their support/funding agencies. The sector agencies produced reports of sectoral surveys/studies (e.g. ODF sustainability study report) too. Some districts, local governments, and communities established WASH resource centres to strengthen documentation, knowledge management, learning, and reporting. The media shared formal information received from the coordination mechanism and also aired their views through national/local newspapers and electronic media (radio and television). The media produced news and reports through their independent monitoring and study as well. The media were affiliated with the sanitation campaign since the beginning but their aggressive engagement with the coordination mechanisms in planning, monitoring, verifying, and reporting was ensured only when the government intensified the campaign in low-sanitation-coverage districts. The incentives and sanctions around honest reporting are set out in Box 3. 


\section{Box 3: Incentives and sanctions for honest reporting and transparency}

\section{Incentives:}

- Engagement of central level team: Nepal missed its deadline of universal sanitation coverage by 2017 due to unforeseen circumstances. This situation provided some relaxation to the government to hear the voice of stakeholders, assess bottlenecks, and revisit lapses. For example, stakeholders at district headquarters in Bhojpur strongly advocated that the true spirit of district ODF declaration could be established only when there were required drainage and faecal sludge management (FSM) facilities in place along with attainment of ODF status. Therefore, the NSHCC sent its members and MAT for on-the-spot monitoring to establish the reality in Bhojpur, Kapilvastu, and other problem-ridden districts. With the facilitation of the NSHCC/central level monitoring team, the district level stakeholders agreed to declare the district ODF and to promote drainage, FSM, and other locally appropriate sanitation systems in district headquarters. This actual/honest reporting became an incentive for national and district/local level governments.

- Collaboration with media: With some incentives, district WASH-CCs had engaged the media and journalists in monitoring, reporting, and documentation. Its secretariat conducted regular press conferences to disseminate progress and data regularly. This collaboration remained fruitful during the campaign's take-off stage and at the point of district ODF declaration. For example, Jhapa district had conducted a 'media mission' as a key strategy that helped to identify community level challenges, and establish sanitation as a core agenda of the district. The headline 'Prime Minister's District (Jhapa) Yet to Achieve ODF' published in a renowned national daily produced a big ripple across the country.

- Repeated monitoring: In some places, district WASH-CCs monitored the communities as many as three times to ascertain if the ODF claim of the local WASH-CC was valid.

- Moral and ethical obligation: WASH-CC's due recognition to the members of monitoring team as a major responsibility bearer worked as an important incentive to them to perform honestly. Monitoring teams, along with their joint signature, had to clearly recommend to the district WASH-CC whether to declare the monitored rural municipality/municipality/ VDC areas an ODF zone. Such an ethically guided situation stimulated them to maintain their individual and collective professional integrity.

\section{Sanctions:}

- Cancelation of decision on ODF declaration: The district WASH-CC in Bajura cancelled the ODF declaration of a VDC, indicating that it had failed to solicit proper data and information.

- Penalty: District WASH-CCs, for example, in Rautahat, imposed a strong policy of implementing agencies or VDCs bearing the entire cost of filling the gap, if monitoring revealed slippage of more than $\mathbf{5 \%}$ due to their misleading information/over reporting.

The data/information produced in sector reports were published through media or sector publications. For example, the NSHCC disseminated summaries of these data through a dynamic dash board located at its secretariat, its periodic publication Sarsafai Sandesh (Sanitation Newsletter), and its booklet on Nepal's ODF journey, published on the occasion of the national ODF declaration 
ceremony. The data were fed in to the NMIP and published periodically. The independent monitoring by the media and the Journalist WASH Forum, the engagement of cross-sector monitoring teams, and verification of WASH-CC and collective decision-making process help reduce the chance of reporting being one-sided or biased.

\section{Mechanisms to promote transparency in campaign moni- toring and reporting}

Transparency was fundamental to the sanitation campaign. Target setting, amendments, and promotional activities were decided by common consensus of the WASH-CC members and stakeholders based on field data/evidence. For example, issues and the status of sanitation were openly discussed in district and local level conferences on sanitation and progress-sharing workshops.

The engagement of multi-sector actors in the monitoring and verification team created a culture of transparency. Cross-monitoring helped enhance transparency and identify gaps. Inclusive WASH-CCs, memoranda of understanding-based collaborations between local government and development partners, participatory planning, joint-monitoring, verification monitoring, independent media monitoring, ODF declaration amid wider participation of community members, and sharing of expenditure publicly all helped maintain transparency. The development partners, for example the Global Sanitation Fund programme, adopted output-based payments to their local level implementing agencies, so that the output as envisaged in the memoranda of understanding were achieved in almost all cases.

\section{Participatory mapping}

Figure 3. Social Map of School Catchment Area, Bara.

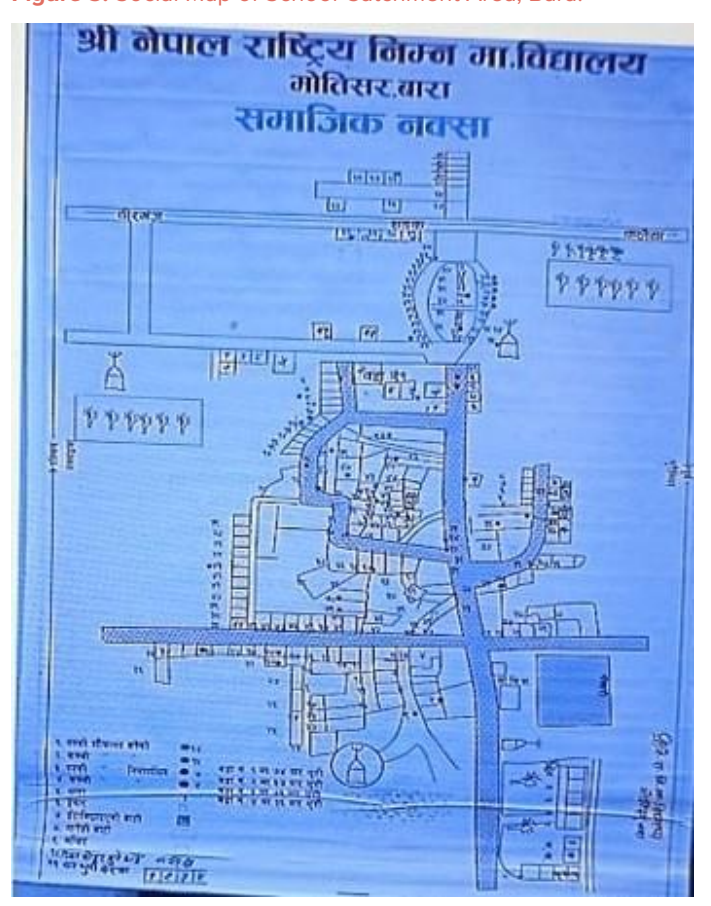

Photo Credit. Kamal Adhikari
During the campaign, social maps, were placed in public places around the community. Thesecomprised data on the total number of houses in the community, and the houses possessing and lacking toilets. In some social maps the name of support organisations and facilitators, and details of the budget spent were also displayed. This arrangement strengthened people's sense of ownership and trust. Often, such maps were developed in smaller communities and schools, for example the social map of the school's catchment area of Nepal National Lower Secondary School in Bara district (Fig.3), as part of triggering/ sensitisation and planning. This data was accurate as community members and students were not guided by any interest in presenting false data, and it was impartially cross-verified by the communities themselves. Such data was eventually integrated into a ward-level data system and updated particularly during monitoring of local level ODF declarations. A social accountability programme (SAP), a form of social audit introduced in Rural Water Supply and Sanitation Fund Development Board-run water sup-
sparency and WASH sector governance. For example, ply and sanitation projects, helped maintain transparency and WASH sector governance. For example,
local communities recovered 0.2 million Nepalese rupees embezzled in Bakhreldi water supply and sanitation project in Kavre district. The transparent mobilisation of sanitation revolving funds promoted toilet and ODF campaigns in the project areas. These achievements resulted from the SAP intervention, which included formation and activation of SAP committees, participatory preparation of a community score card, assessment of budget allocation, and a review of achievements (Adhikari 2020). 
The mapping of stakeholders and their resources, which was a vital part of local level strategic planning, contributed to avoiding resource gaps as well as to identifying resource overlap. The memorandum-of-understanding-based partnership prevented implementing agencies from entering into programme areas in a non-transparent manner. On top of that, the process of sharing of data, expenditure, achievements, and progress in the joint progress review and planning workshops made up of WASH-CCs and stakeholders made support organisations and implementing agencies accountable for their reporting, even though some local level implementers had an affinity towards exaggerating their progress in front of their support/funding organisations.

\section{Process of national declaration}

Nepal was declared an ODF nation after a four-decade-long, ceaseless effort on the part of the state and stakeholders. The priority the state gave to securing ODF status on the national agenda, constitutional recognition of sanitation as a fundamental right, the state's commitments made in regional and global forums, the national aspiration for graduation towards total sanitation, citizens' progressive realisation of sanitation as a basis of health, and communities' strong desire to be free from stigma were decisive forces that propelled the national declaration.

The campaign was fully supported by all political parties so that the government and high-level political leaders were closely watching to determine whether the ODF claims made at various levels were real. The state's eventual ODF claim was the result of an accumulation of the claims made by national and sub-national level coordination mechanisms and stakeholders. There was active participation of the representatives of three tiers of the government, districts, development partners, the media, and civil society organisations, and positive comments from the latter and from development partners.

The United Nations Resident Coordinator, the Country Representative of Water Aid Nepal, and the national president of the Federation of Drinking Water Supply and Sanitation Users lauded the success of Nepal's ODF campaign promoted through the government's leadership, the collaboration of stakeholders, and enforcement of the Master Plan. They also emphasised the need to sustain the gain thus made. The representatives of the federal and provincial ministers highlighted the need for upgrading facilities and post-ODF intervention aiming to maintain the quality and sustainability of facilities and behaviours (NSHCC 2020). Their positive comments clearly showed that the ODF claim was inclusive and credible even though there was some criticism through social media and national dailies. On the occasion, the need for formulation of the Total Sanitation Master Plan was also emphasised.

Led by the secretary of the lead Ministry of WASH sector and comprising members from the National Planning Committee (NPC) and six related ministries, the National Sanitation and Hygiene Steering Committee (NSHSC) was institutionalised as a supreme body to make decisions on implementing the Master Plan, review effectiveness of sectoral activities, lead national initiatives on sanitation, and endorse sectoral documents. Importantly, the NPC and related ministries, as well as the leadership of the lead sector ministry, fully owned the national declaration. This was a sufficient basis for the state authority to make a national ODF declaration - a momentous milestone of sanitation. The main concern of the state and stakeholders was to look at the achievement of ODF status as an entry point only for stepping up to the next critical phase of total sanitation, ultimately aiming to achieve the Sustainable Development Goal on sanitation.

For national ODF declaration, established protocols and ownership of three levels of government and districts and their respective coordination mechanisms were duly followed. The joint meeting of NSHSC, NSHCC, and stakeholders held on 25 September 2019 made a unanimous decision to declare the nation ODF. The active participation of concerned cross-sector stakeholders, including collaborating development agencies, in all the meetings about national ODF declaration, manifested everyone's support for achieving the last milestone set by the Master Plan and embarking on the next journey of sanitation - total sanitation. On 30 September 2019, the Rt. Hon'ble Prime Minister of Nepal declared Nepal an ODF nation with due recognition to ODF declarations made by 753 local governments and 77 districts, which had generated primary data on sanitation from communities 
and wards.

Local level WASH-CCs had declared their villages/wards by ensuring access for all households to toilets. However, WASH-CCs accepted the presence of community toilet for landless people. Such toilets were installed by local governments and community-level philanthropists. The Master Plan approved by the government of Nepal (Council of Minister) had authorised multi-sector coordination mechanisms (NSHSC, NSHCC, and WASH-CCS) for undertaking monitoring, verification, and declaration. Further, WASH-CCs had followed the standard monitoring, verification monitoring, and declaration protocol as developed and endorsed collectively through local level strategic plans/ plans of action on sanitation. The stake, participation, and decision of a wide range of stakeholders was ensured in the entire declaration process. The monitoring, verification, and declaration by WASH-CCS were thus valid and authentic.

A minor criticism surrounding the level of use of toilets surfaced through social and mass media before the national declaration. However, the state wished to move towards the second milestone of sanitation (total sanitation) and to address any remaining shortcomings of the first milestone (ODF) in the SDG era. The protocol of decentralised, participatory, and valid monitoring and verification, as well as endorsement by local and district level WASH-CCs, was trusted and accepted by all. The state-run and community-owned legitimate national sanitation campaign was widely accepted, credible, and evidence-based. Furthermore, the government and development partners were concerned with safely managed sanitation for all as a post-ODF intervention to fulfil total sanitation goals and the SDG targets.

\section{Challenges to address}

- Frequent transfer of government employees, inadequacy of logistical support, lack of reliable data, and ineffective use of IT application in data/information management were some of the challenges that hampered effectiveness in target setting, monitoring, and knowledge management.

- Target and mission driven sanitation campaigns, if not monitored and assessed closely, properly, and transparently by designated authorities, are likely to suffer from slippage/regression and over-reporting of achievements.

- Continuous reconstruction/maintenance of toilets is essential, particularly in flood affected areas.

- Addressing slippage in toilet use requires total sanitation interventions aiming to promote operation and maintenance/upgrading of toilets, and follow up in behavioural change communication and monitoring.

- Slippage/regression is slowly being reduced due to increasing awareness in the community and community level self-monitoring, but it is a natural, dynamic, and never-ending process. Continuous promotional efforts by the local governments and WASH-CCs should promote joint monitoring (by WASH-CCS) and self-monitoring (by the community) to mitigate slippage and retain achievements. The NSHCC-led ODF sustainability study of 2016 provided practical insight about factors contributing to slippage/regression. For example, the promotion of local technologies and innovative financing mechanisms were crucial, because the cost of sanitation was closely related to the sustainability of ODF status. Such issues identified by studies, surveys, media reporting, and field monitoring were discussed thoroughly in review, planning, and progress sharing meetings/workshop of district and local level WASH-CCs to identify corrective actions.

\section{Practical tips for targeting and monitoring for campaigns}




\section{Commitment of state and stakeholders}

- The national-level target on sanitation worked as a constant reminder and cultivated the accountability of national and sub-national level government entities, coordination mechanisms, and stakeholders to achieve national ODF status within the deadline. The national target was divided into different timelines/milestones (62 per cent by 2012/13, 80 per cent by 2014/15 and 100 per cent by 2016/17), allowing the national sanitation campaign to strategise through milestone-specific learning. For example, the NSHCC launched the 'Terai Sanitation Mission' from 2014, taking in to account stakeholders' reluctance to work in the Terai districts and low sanitation coverage there.

- Declaration papers jointly issued by stakeholders through sanitation conferences entailed joint commitments of the government entities, members of coordination mechanisms, crosssector actors, stakeholders, the media, and CSOs. It made them collectively responsible and accountable for setting/amending the target, running promotional activities, undertaking monitoring, verifying outputs, and fulfilling the target within the deadline.

\section{Locally adapted and owned targets}

- $\quad$ Each district and local level enforced their separate ODF intervention plan (strategic plan/plan of action), set their target and milestones independently, while considering their on-the-ground reality and the national deadline, and adopted tailor-made approaches and indigenous tools for empowerment and sensitisation of community members and cross-sector stakeholders.

- Although the municipality/VDC was considered a base unit of planning, rolling out ODF declarations gradually from toles, wards, and school catchment areas then to municipality/VDC and districts remained an effective strategy to meet the target with full community ownership and leadership.

- The process of persuading economically well-off households to build toilets themselves before stimulating the poor and disadvantaged led to the channelling of scarce resources to needy sections of society. To achieve the universal target it is necessary to target well-off households first.

- The national target needs to be divided into different milestones at district and local levels for effective coordination, planning, monitoring, and motivation.

\section{Transparency fostered through effective monitoring and reporting}

- District and local level joint-monitoring enhanced stakeholders' collective responsibility to map out actual field situations, cross-check existing data, and promote a culture of true reporting.

- National and sub-national coordination mechanisms had strengthened ownership, transparency, and impartiality in target setting, monitoring, verification and ODF declaration.

- Joint-monitoring and quality monitoring undertaken by local and district WASH-CCs adopting standard monitoring protocols were major instruments to identify over reporting, false reporting, transparency, and regression.

- $\quad$ The media played two important roles: it aired mass sensitising activities and success stories as a member of the WASH-CC and also pin-pointed weaknesses and flaws as the watchdog of the campaign. Newspapers and social media were popular and effective tools to critically express opinion about reality of the target, achievements and flaws of the campaign,. For example, in Jhapa district, coverage of critical stories/reporting by the media led to the establishment of an 'aggressive media mission' oriented to undertake community monitoring and evidence-based reporting as well as to run the count down for ODF declaration.

\section{Community monitoring and feedback mechanisms}

- Monitoring and verification undertaken by smaller units (local and ward level WASH-CCS) was found to be closer to field reality than that carried out by district WASH-CCs; this was due to a larger sample size for monitoring and their proximity to communities. In particular, ward level 
verification monitoring was effective for checking data discrepancies.

- Self-monitoring in communities through community groups, women's groups and school children's clubs was instrumental to prevent data discrepancies and false reporting because those groups were free from any influence/vested interest; they were fully aware of the community situation and monitoring was undertaken in 100 per cent of households. Joint-monitoring corrected lapses in self-monitoring, if any, through community consultation.

- People (especially at ward level), had an opportunity to raise/report abuses of programme implementing agencies or the facilitation of WASH-CCs regarding the promotion and use of toilets and attainment of ODF status during monitoring, verification, monitoring, and the ODF declaration ceremony. Reports could also be made through Facebook. The concerned WASHCCs accounted for community members' grievances and were very close to people. This was observed in the Thakurdwara VDC in Bardiya district. However, there were no repercussions for anyone posting critical and negative comments concerning any issues surrounding the ODF campaign.

\section{References}

Adhikari, K. (2015) Sanitation in Nepal: Past, Present and Future, Kunti Bhoomi Memorial Trust

Adhikari, T. (2020) 'Social Accountability Program for Effectiveness in Water Supply and Sanitation Program', Nepal Paani (Nepal Water) Newsletter (Magh 2076 BS-Paush 2077 BS, Year-4, Issue-1, Combined Issue-5), Department of Water Supply and Sewerage

Government of Nepal (2011) Sanitation and Hygiene Master Plan

Law Book Management Committee, Constitution of Nepal, 2072 BS

Ministry of Physical Planning and Works (MPPW) (2004) Rural Water Supply and Sanitation National Policy, Strategy and Sectoral Strategic Action Plan

Ministry of Water Supply and Sanitation (2017) Total Sanitation Guidelines

Ministry of Education and Sports, WASH in School Procedure, 2074 BS

MPPW (2011) WASH Sector Status Report

National Planning Commission (NPC) and UNDP Nepal (2012) Nepal Millennium Development Goal Acceleration Framework (Sanitation)

NPC and UNICEF (2019) Multi Indicator Cluster Survey

National Sanitation and Hygiene Coordination Committee (NSHCC) and UNICEF Nepal (2016) Final Report on ODF Sustainability Study in Nepal

NSHCC (2020) Booklet on ODF Journey in Nepal

Shrestha, S., Ahmad, T., and Shrestha, P. K. (2018) Sustainability of ODF in Nepal, Paper Submitted to 41th WEDC International Conference, Egerton University, Nakuru, Kenya

UN-Habitat (2017) Report on Sustainability of ODF Campaign in GSF Supported Program Districts

Water Supply and Sanitation Collaborative Council (WSSCC) (2019) Sprinting the Last Mile: Nepal's Sanitation Campaign in the Terai 
For over ten years, IDS's Sanitation Learning Hub (SLH, previously the CLTS Knowledge Hub) has been supporting learning and sharing across the international sanitation and hygiene (S\&H) sector. The SLH uses innovative participatory approaches to engage with both practitioners, policy-makers and the communities they wish to serve.

We believe that achieving safely managed sanitation and hygiene for all by 2030 requires timely, relevant and actionable learning. The speed of implementation and change needed means that rapidly learning about what is needed, what works and what does not, filling gaps in knowledge, and finding answers that provide practical ideas for policy and practice can have exceptionally widespread impact.

Our mission is to enable the S\&H sector to innovate, adapt and collaborate in a rapidly evolving landscape, feeding learning into policies and practice. Our vision is that everyone is able to realise their right to safely managed sanitation and hygiene, making sure no one is left behind in the drive to end open defecation for good.

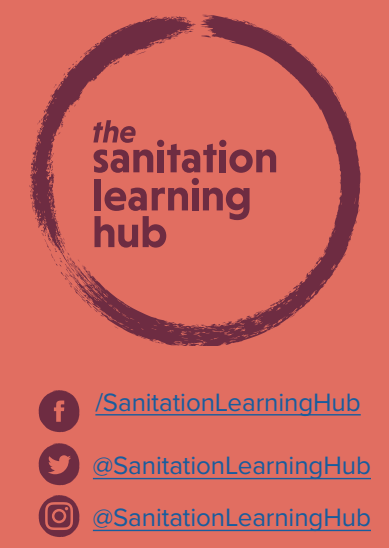

Correct citation: Adhikari, K. and Adhikari Sharma, B. (2021) Case Study 1: Nepal Sanitation Movement Lessons Learnt on Targets and Monitoring, The Sanitation Learning Hub, Brighton: IDS, DOI: $10.19088 /$ SLH.2021.012

First published in 2021

(c) Institute of Development Studies 2021

Some rights reserved - see copyright license for details.

ISBN: 978-1-78118-814-9

For further information please contact:

The Sanitation Learning Hub, Institute of Development

Studies, University of Sussex, Brighton, BN1 9RE

Tel: +44 (0)1273 606261

Email: SLH@ids.ac.uk

This series is licensed under the Creative Commons Attribution-Non-Commercial-NoDerivs 3.0 Unported License (https://creativecommons.org/licenses/by-nc-nd/3.0/).

Attribution: You must attribute the work in the manner specified by the author or licensor.
Non-commercial: You may not use this work for commercial purposes No Derivative Works: You may not alter, transfer, or build on this work.

Users are welcome to copy, distribute, display, translate or perform this work without written permission. For any reuse or distribution, you must make clear to others the licence terms of this work. If you use the work, we ask that you reference SLH and send a copy of the work or a link to its use online to the following address: The Sanitation Learning Hub, Institute of Development Studies, University of Sussex, Brighton, BN1 9RE (SLH@ids.ac.uk).

\section{c. creative}

This document has been financed by the Swedish International Development Cooperation Agency, Sida. Sida does not necessarily share the views expressed in this material. Responsibility for its contents rests entirely with the authors. 